\title{
Expression of a functional CCR7 chemokine receptor inhibits the post-intravasation steps of metastasis in malignant murine mammary cancer cells
}

\author{
STEFANIA CROCI ${ }^{1}$, GIORDANO NICOLETTI ${ }^{2}$, LORENA LANDUZZI ${ }^{2}$, ARIANNA PALLADINI $^{1}$, \\ FRANCESCA CHIARINI $^{1}$, PATRIZIA NANNI ${ }^{1}$, PIER-LUIGI LOLLINI ${ }^{1}$ and CARLA DE GIOVANNI ${ }^{1}$ \\ ${ }^{1}$ Cancer Research Section, Department of Experimental Pathology, University of Bologna, Viale Filopanti 22, \\ I-40126 Bologna; ${ }^{2}$ Rizzoli Orthopaedic Institute, Via di Barbiano 1/10, I-40136 Bologna, Italy
}

Received February 6, 2007; Accepted March 22, 2007

\begin{abstract}
To study the role of the chemokine receptor CCR7 in the metastatic process, a murine CCR7 gene was transduced in two mammary cancer cell lines with different origins and molecular features; TS/A, derived from a spontaneous mammary cancer of BALB/c strain, and N202.1A, derived from a HER-2/neu transgenic mammary cancer (FVB background) and characterized by a high expression of HER-2/ neu. Transduced CCR7 conferred to mammary cancer cells a chemotactic response towards CCL21 (a CCR7 ligand), but did not consistently affect in vitro growth properties. In vivo, CCR7-engineered cells gave rise to tumors in syngeneic hosts with growth rates similar to or slightly lower than the controls and with similar patterns of spontaneous metastases. When injected directly intravenously to study the late post-intravasation phases of metastasis, CCR7-engineered cells showed a strongly decreased lung colonizing ability. Such an effect was observed both with HER-2/neu-positive and -negative mammary cancer cells. When used as a prophylactic vaccine, CCR7-transduced cell vaccine succeeded in the long-term control of mammary tumorigenesis in $25 \%$ of the HER-2/neu transgenic females, suggesting an increased immunogenicity of CCR7-engineered cells.
\end{abstract}

\section{Introduction}

Metastasis is a hallmark of cancer (1) and is the main cause of death in cancer patients. It results from a multistage process, starting with invasion at the primary tumor site, followed by dissemination by the hematogenous or lymphatic route with arrest in distant organs, and ending with a distant-site

Correspondence to: Dr Carla De Giovanni, Cancer Research Section, Department of Experimental Pathology, University of Bologna, Viale Filopanti 22, I-40126 Bologna, Italy

E-mail: carla.degiovanni@unibo.it

Key words: mammary cancer, metastasis, CCR7, HER-2, gene transduction colonization, consisting in the conversion of disseminated single cancer cells into proliferating, proangiogenic secondary tumors. Each phase is likely governed by specific molecular mechanisms which are still incompletely understood $(2,3)$.

Experimental models to evaluate the role played by candidate molecules in the metastatic process can take advantage of gene engineering to modify gene expression on the one hand (4), and several methods to induce metastasis on the other, for example the direct intravenous injection of cells that simulate the late, post-intravasation phases of metastasis (5).

Some chemokine receptors have been suggested to play a role in metastasis (6-9), CXCR4 and CCR7 being the most important candidates. Chemokine receptors are physiological mediators of the directed migration of leukocytes along a chemical gradient of ligand (10). An ectopic expression of the chemokine receptor CXCR4 was observed in a large series of human tumors with different histotypes and was, in some cases, correlated with lymphatic and distal dissemination; CCR7 expression was found to be correlated with metastasis in squamous-cell carcinoma and non-small-cell lung cancer (8). The potential role for CXCR4 and CCR7 receptors in the metastatic process has been confirmed by a few gene transduction studies $(11,12)$, which used, as a recipient for gene transfer, non-epithelial tumor cells, such as T-cell hybridoma and melanoma. However in experiments studying the induction of metastatic ability by gene modifications, the histotype of origin is not irrelevant; in particular, mammary cells are profoundly different from melanocytes, the latter having a pro-metastatic gene expression machinery (13).

Breast cancer can show expression of CXCR4 and CCR7, and display a migratory response to their ligands (14). Functional demonstrations of the role played by CXCR4 in breast cancer metastasis were obtained through CXCR4 blocking by means of neutralizing antibodies, a selective synthetic polypeptide or siRNA (14-16). Upregulation of CXCR4 expression is essential for HER-2/neu-mediated tumor metastasis (17). On the contrary, the role of CCR7 in metastasis of mammary carcinoma still needs to be investigated through functional approaches.

In this study the role of the chemokine receptor CCR7 in mammary cancer metastasis was investigated through the 
transduction of a CCR7 gene. We used, as recipients, two mammary cancer cell lines with different origins and molecular features; TS/A, derived from a spontaneous mammary cancer of BALB/c strain (18), and N202.1A, derived from a mammary cancer arisen in the N\#202 HER-2/neu transgenic line (FVB background) and characterized by the expression of HER-2/neu (19).

\section{Materials and methods}

CCR7 gene transduction. Two cell lines of murine mammary carcinoma were used for gene transduction; TS/A (18) and N202.1A (19). Cells were cultured in Dulbecco's modified Eagle's medium (DMEM) supplemented with fetal bovine serum (FBS), $10 \%$ for TS/A and $20 \%$ for $\mathrm{N} 202.1 \mathrm{~A}$, at $37^{\circ} \mathrm{C}$ in $5 \% \mathrm{CO}_{2}$ atmosphere. All media constituents were from Invitrogen, Milan, Italy. Expression vector pLNCX2-CCR7, carrying the murine cDNA gene for CCR7 (20), was kindly provided by Dr S. Hwang (National Cancer Institute, Bethesda, MD) (12). Cells were plated in 100-mm Petri dishes at $10^{6}$ cells/dish in $10 \mathrm{ml}$ of culture medium. After $24 \mathrm{~h}, 2 \mu \mathrm{g} /$ dish of pLNCX2-CCR7 or pLNCX2 (empty vector) was transfected by calcium phosphate precipitation (Invitrogen). Transduced cells were positively selected in the presence of G418 (Invitrogen) at a concentration of $800 \mu \mathrm{g} / \mathrm{ml}$. After selection, cultures were routinely maintained in $500 \mu \mathrm{g} / \mathrm{ml}$ of G418.

Real-time RT-PCR. Total RNA was extracted from cell lines by TRIzol reagent. Total RNA ( $1 \mu \mathrm{g})$ was reverse-transcribed using reverse transcriptase in the presence of random hexamers. CCR7 expression was analysed by quantitative real-time RT-PCR using an ABI PRISM 5700 sequence detection system (Applied Biosystems, Applera, Milan, Italy), with CCR7 primers and under conditions reported in the literature (12). Relative quantification of the mRNA levels of CCR7 was determined using the $\Delta \Delta \mathrm{Ct}$ method, and the results were expressed as fold difference in expression of CCR7-engineered cells relative to untransduced recipient cells.

Cytofluorometric studies. CCR7 membrane expression was studied through a fusion protein CCL19-IgG2b, kindly provided by Dr Krautwald, University of Schleswing-Holstein, Kiel, Germany (21). Harvested cells were incubated with $50 \mu 1$ of CCL19-IgG2b at $4^{\circ} \mathrm{C}$ for $30 \mathrm{~min}$, washed and incubated with $50 \mu \mathrm{l}$ of 1:20 diluted rabbit anti-human IgG antiserum (Behring, Marburg, Germany) at $4^{\circ} \mathrm{C}$ for $30 \mathrm{~min}$. After the final washings, cells were re-suspended in phosphate-buffered saline containing $1 \mu \mathrm{g} / \mathrm{ml}$ of ethidium bromide to gate out dead cells and were subjected to cytofluorometric analysis with a FACScan (Becton Dickinson, St. Jose, CA). HER-2/ neu membrane expression was studied using a 1:20 dilution of the monoclonal antibody 7.16.4 recognizing rat neu antigen (Oncogene Research Products, San Diego, CA), and a secondary goat anti-mouse IgG antibody (Euroclone, Milano, Italy), diluted 1:20. Conditions and analysis were as above.

Migration assay. Migration assay was conducted using Transwell chambers (Costar, Cambridge, MA) with 8-mm pore size, polyvinylpyrrolidone-free polycarbonate filters.
DMEM supplemented with 20-400 nM CCL21 (Peprotech, London, UK) was placed in the lower compartment, whereas $5 \times 10^{5}$ cells re-suspended in DMEM were seeded in the upper compartment and incubated overnight at $37^{\circ} \mathrm{C}$ in a $7 \% \mathrm{CO}_{2}$ atmosphere. Cells that migrated through the filter to reach the lower chamber were counted with an inverted microscope. The chemotaxis index was calculated as: (number of cells migrated toward CCL21 gradient/number of cells migrated in the absence of CCL21)x100.

In vitro growth. To determine population doubling time of adherent cultures, $5 \times 10^{5}$ viable cells were seeded in $25-\mathrm{cm}^{2}$ flasks, and growth curves were obtained by a direct count of cells harvested with trypsin-EDTA for 5 days after seeding. For anchorage-dependent clonogenicity, 200-6,400 cells were seeded in $60-\mathrm{mm}$ tissue culture Petri dishes in DMEM $+20 \%$ FBS. After 14 days, colonies were fixed in methanol, stained with Giemsa and counted with an inverted microscope at low magnification. Anchorage-independent cloning efficiency was determined by suspending $10^{4}$ to $2 \times 10^{5}$ cells in DMEM + 20\% FBS containing $0.33 \%$ agar. Cell suspensions were then layered on a $5-\mathrm{ml}$ base of $0.5 \%$ agar in $60-\mathrm{mm}$ Petri dishes. Colony growth was monitored twice weekly and determined by counting at low magnification 14 days after seeding. To study the effect of CCL21 on cell proliferation, cells were seeded in 96-well Multiwell Falcon plates $\left(10^{4}\right.$ cells/ well) in DMEM + 1\% FBS. After $24 \mathrm{~h}$, CCL21 was added at concentrations ranging from $60-240 \mathrm{ng} / \mathrm{ml}$ (corresponding to 5-20 nM). Cell growth was evaluated after a further 48- to 72-h incubation with the addition of $10 \mu \mathrm{l} /$ well of WST-1 (Cell proliferation reagent, Roche, Monza, Italy), and by a reading of 450/620-nm absorbance in a Sunrise plate reader (Tecan, Switzerland). Results were expressed as \% of control cultures performed in parallel in the absence of the chemokine.

In vivo studies. To study tumorigenicity TS/A and its transduced cells $\left(5 \times 10^{4}\right)$ were injected subcutaneously (s.c.) into the right inguinal region of syngeneic 8- to 12-week-old BALB/cAnNCRL mice (Charles River Laboratories, Calco, Italy), whereas N202.1A and its transduced cells $\left(10^{6}\right.$ cells $)$ were injected into healthy 8 - to 16-week-old female syngeneic N\#202 HER-2/neu transgenic mice (22) from our colony (23). Tumor incidence and growth were evaluated weekly. Neoplastic masses were measured with calipers; tumor volume was calculated as $\pi / 6 \times[\sqrt{ }(\mathrm{axb})]^{3}$ in which $a$ and $b$ were two perpendicular major diameters. Experimental metastases were evaluated 30 days after the injection in a lateral tail vein of $5 \times 10^{4}$ or $10^{5}$ cells for TS/A and N202.1A models, respectively. To evaluate lung metastases, lungs were contrasted with black India ink, and metastases were counted in dissected lung lobes under a stereoscopic microscope. For the evaluation of vaccine efficacy of $1 \mathrm{~A}-\mathrm{CCR} 7-\mathrm{C} 11$ cells, HER-2/neu transgenic mice with a BALB/c background (BALBneuT mice) from our colony were used (23). Starting at the sixth week of age, BALB-neuT mice entered the vaccination protocol, consisting of 2 weeks of bi-weekly intraperitoneal (i.p.) vaccinations with $2 \times 10^{6}$ mitomycin Ctreated engineered cells in $0.4 \mathrm{ml}$ of PBS, followed by 1 week of five daily i.p. administrations (50 ng in the first course and $100 \mathrm{ng}$ thereafter) of mouse rIL-12 (kindly provided by 


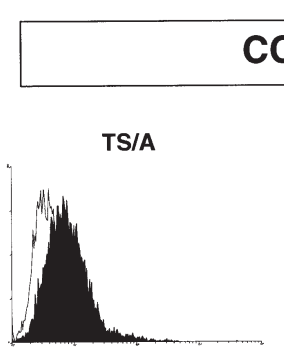

TS/A-neo

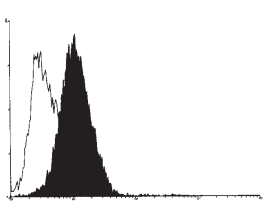

TS/A-CCR7-C1
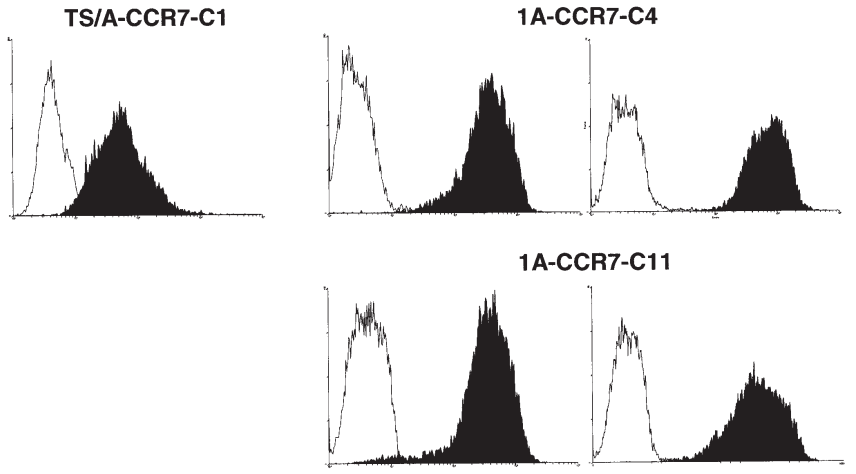

Figure 1. Flow cytometric analysis of CCR7 and neu membrane expression in transduced murine mammary carcinoma cells. In each panel the abscissa is fluorescence intensity on a logarithmic scale ranging from $10^{0}$ to $10^{4}$, and the ordinate is the number of cells. Open profiles represent cells stained with secondary antibody alone, and dark profiles represent cells stained for the indicated antigen

Dr S. Wolf, Genetics Institute, Andover, MA), and 1 week of rest. Vaccination cycles were repeated lifelong (24).

\section{Results}

CCR7 expression and function. TS/A and N202.1A cell lines were transduced with an expression vector carrying the cDNA
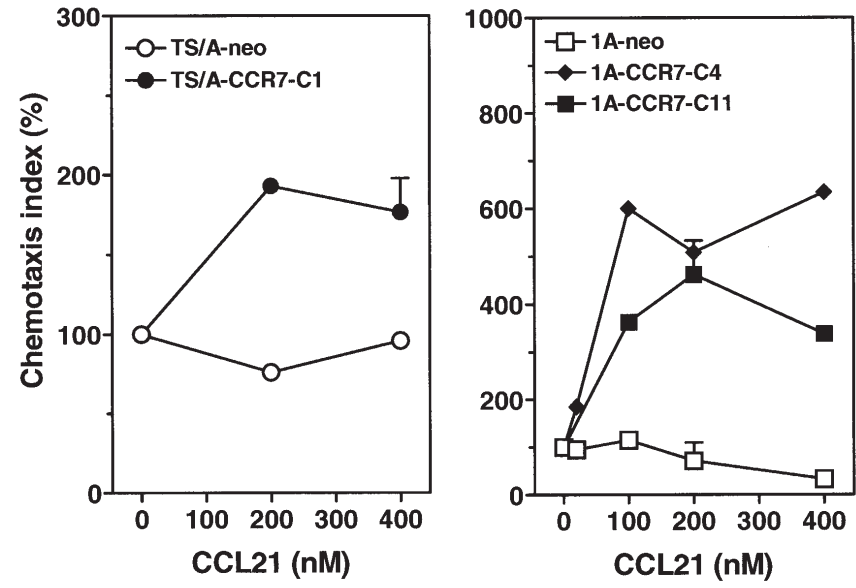

Figure 2. Chemotactic response of CCR7-engineered murine mammary carcinoma cells to different concentrations of CCL21. The chemotaxis index was calculated as: (number of cells migrated toward CCL21 gradient/ number of cells migrated in the absence of CCL21)x100. The mean $\pm \mathrm{SE}$ of 2 replicates is shown.

for murine CCR7 or with the corresponding empty vector. A wide panel of clones were screened for CCR7 expression by real-time RT-PCR, and the highest expressors were chosen: for TS/A cell line, clone TS/A-CCR7-C1 expressed up to $10^{5}$-fold more CCR7 than parental cells or neo-resistant transduction controls, whereas for N202.1A cells, clones 1A.CCR7-C4 and 1A.CCR7-C11 expressed respectively $\sim 1$ and 3 million-fold more CCR7 than controls.

All the CCR7-engineered clones selected showed membrane expression of the chemokine receptor as seen by indirect immunofluorescence and cytofluorometric study (Fig. 1). CCR7-engineered N202.1A clones displayed the highest values of CCR7 membrane expression, while keeping unaltered a high HER-2/neu expression.

All the CCR7-engineered clones studied showed a migratory response to CCL21 (a CCR7 ligand) in a standard migration assay (Fig. 2); the higher migratory response observed with N202.1A-engineered clones paralleled the higher CCR7 membrane expression. Therefore transduced

Table I. In vitro growth properties of CCR7-engineered mammary cancer cells.

\begin{tabular}{|c|c|c|c|c|c|}
\hline Cells & $\begin{array}{c}\text { Gene } \\
\text { modification }\end{array}$ & $\begin{array}{l}\text { Doubling time } \\
\text { (h) }\end{array}$ & $\begin{array}{l}\text { Anchorage-dependent } \\
\text { cloning efficiency } \\
(\%)\end{array}$ & $\begin{array}{l}\text { Anchorage-independent } \\
\text { cloning efficiency } \\
(\%)\end{array}$ & $\begin{array}{c}\text { Proliferative response } \\
\text { to CCL } 21^{\mathrm{a}} \\
(\% \text { of control })\end{array}$ \\
\hline TS/A & none & $13.2 \pm 0.9$ & $29.9 \pm 1.3$ & $6.8 \pm 1.3$ & $114.0 \pm 12.9$ \\
\hline TS/A-neo & $n e o^{r}$ & $13.4 \pm 1.2$ & $26.1 \pm 0.5$ & $7.0 \pm 0.9$ & $90.0 \pm 2.2$ \\
\hline TS/A-CCR7-C1 & $\mathrm{neo}^{\mathrm{r}}+\mathrm{mCCR} 7$ & $13.7 \pm 1.0$ & $28.2 \pm 0.7$ & $11.8 \pm 1.3$ & $100.6 \pm 4.7$ \\
\hline N202.1A & none & $26.1 \pm 1.2$ & $8.1 \pm 1.3$ & 0.6 & $104.0 \pm 7.7$ \\
\hline 1A-neo & $n e o^{r}$ & $23.7 \pm 1.5$ & $2.8 \pm 0.4^{\mathrm{b}}$ & 1.0 & $96.3 \pm 2.5$ \\
\hline 1A-CCR7-C4 & $\mathrm{neo}^{\mathrm{r}}+\mathrm{mCCR} 7$ & $23.1 \pm 0.3$ & $8.1 \pm 1.2$ & 0.4 & $102.9 \pm 3.3$ \\
\hline 1A-CCR7-C11 & $\mathrm{neo}^{\mathrm{r}}+\mathrm{mCCR} 7$ & $37.5 \pm 1.5^{\mathrm{b}}$ & $4.6 \pm 0.3^{b}$ & 0.1 & $96.4 \pm 17.1$ \\
\hline
\end{tabular}

aData refer to $240 \mathrm{ng} / \mathrm{ml} \mathrm{CCL21.} \mathrm{Similar} \mathrm{results} \mathrm{were} \mathrm{obtained} \mathrm{with} \mathrm{lower} \mathrm{CCL21} \mathrm{doses.}{ }^{\mathrm{b}} \mathrm{p}<0.05 \mathrm{vs}$ corresponding untransduced cells (Student's t-test). 

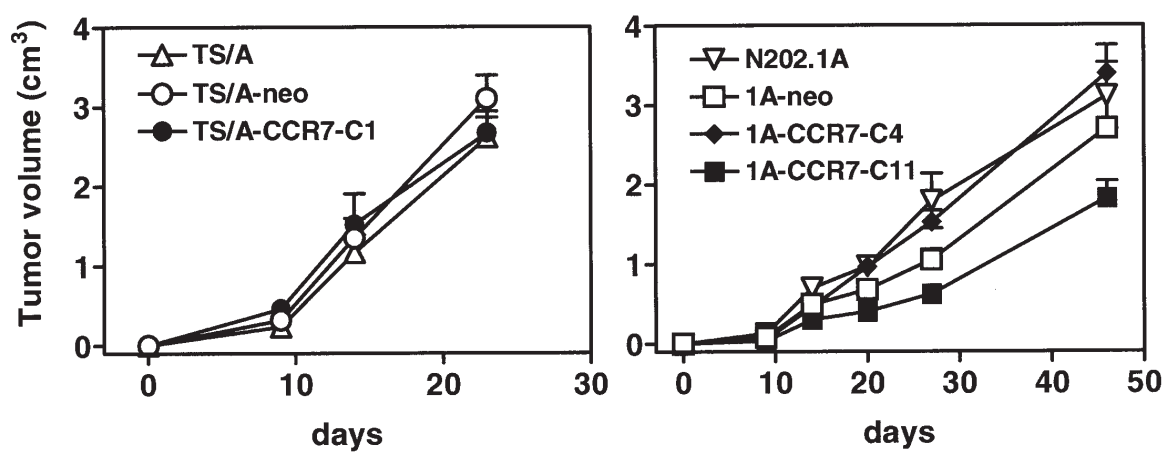

Figure 3. Tumorigenic ability of CCR7-engineered mammary cancer cells in syngeneic hosts. TS/A cells and derivatives were injected into BALB/c mice; N202.1A cells and derivatives were injected into N\#202 HER-2/neu transgenic mice (FVB background). Each point represents the mean and SE (5 mice per group). From day 14 after cell injection onwards, tumor volumes induced by 1A-CCR7-C11 were significantly lower than those induced by N202.1A (p<0.05, Student's t-test).

Table II. Metastatic ability of CCR7-engineered mammary cancer cells in syngeneic hosts.

\begin{tabular}{|c|c|c|c|c|c|c|c|}
\hline \multirow[t]{2}{*}{ Cells } & \multirow[t]{2}{*}{$\begin{array}{l}\text { Gene } \\
\text { modification }\end{array}$} & \multicolumn{3}{|c|}{$\begin{array}{l}\text { Spontaneous lung metastases } \\
\text { (tumor-bearing mice) }\end{array}$} & \multicolumn{3}{|c|}{$\begin{array}{l}\text { Experimental lung metastases } \\
\text { (i.v. cell injection) }\end{array}$} \\
\hline & & Incidence $(\%)$ & $\begin{array}{l}\text { Median } \\
\text { number }\end{array}$ & Range & Incidence $(\%)$ & $\begin{array}{l}\text { Median } \\
\text { number }\end{array}$ & Range \\
\hline $\mathrm{TS} / \mathrm{A}$ & none & $5 / 5(100)$ & 20 & $1-48$ & $5 / 5(100)$ & 117 & $54-136$ \\
\hline TS/A-neo & neo $^{r}$ & $5 / 5(100)$ & 17 & $5-69$ & $5 / 5(100)$ & $45^{\mathrm{a}}$ & $30-88$ \\
\hline TS/A-CCR7-C1 & $\mathrm{neo}^{\mathrm{r}}+\mathrm{mCCR} 7$ & $4 / 5(80)$ & 28 & $0-54$ & $5 / 5(100)$ & $12^{\mathrm{b}}$ & $7-22$ \\
\hline N202.1A & none & 4/7 (57) & 1 & $0-3$ & $5 / 5(100)$ & 76 & $60-111$ \\
\hline 1A-neo & neo $^{r}$ & $1 / 4(25)$ & 0 & $0-2$ & $5 / 5(100)$ & 72 & $10-96$ \\
\hline 1A-CCR7-C4 & $\mathrm{neo}^{\mathrm{r}}+\mathrm{mCCR} 7$ & $4 / 5(80)$ & 2 & $0-6$ & n.d..$^{c}$ & & \\
\hline 1A-CCR7-C11 & $\mathrm{neo}^{\mathrm{r}}+\mathrm{mCCR} 7$ & $1 / 5(20)$ & 0 & $0-1$ & $1 / 5(20)$ & $0^{\mathrm{b}}$ & $0-1$ \\
\hline
\end{tabular}

${ }^{\mathrm{a}} \mathrm{p}<0.05$ vs corresponding untransduced cells (non-parametric rank sum test). ${ }^{\mathrm{b}} \mathrm{p}<0.01$ vs corresponding untransduced cells and vs transduction neo controls (non-parametric rank sum test). ${ }^{\mathrm{c}}$.d., not done.

CCR7 chemokine receptor was functional in murine mammary cancer cells.

In vitro growth of CCR7-engineered cells. We studied several parameters of in vitro growth of CCR7-engineered cells and controls (both parental cells and transduction controls), such as the doubling time, the cloning efficiency (both anchoragedependent and -independent) and the growth in the presence of CCL21 (Table I). No parameter was consistently altered in association with CCR7, therefore CCR7 did not influence the in vitro growth of mammary cancer cells.

Tumorigenic and metastatic ability. All the CCR7-engineered clones of both origin (TS/A and N202.1A) maintained the ability to grow as subcutaneous tumors in syngeneic mice, with in vivo growth rates close or slightly lower than those of the respective controls (Fig. 3). Spontaneous metastatic ability of CCR7-engineered clones resembled that of the parental cell line (Table II); a very low ability to give rise to lung metastasis was observed with the N202.1A cell line and their CCR7engineered cells, whereas TS/A and CCR7-transduced TS/A cells displayed a high ability to metastasize spontaneously to the lungs.

However, when the late phases of the metastatic process were studied through cell injection directly into the blood stream, CCR7-engineered cells of both cell lines induced a significantly decreased number of lung metastases (Table II).

Immunogenicity of CCR7-engineered cells. HER-2/neu transgenic mice are a model for mammary carcinogenesis, since they show a progression from hyperplastic mammary gland to in situ carcinoma and then to invasive tumors resembling that observed in humans (23). In particular, HER-2/ neu transgenic females with the BALB/c background (BALBneuT mice) developed mammary carcinomas in all 10 mammary glands, with the first tumor occurring between 20 and 25 weeks of age. We previously found that vaccination of tumor-free 6-week-old mice with allogeneic HER-2/neupositive cells (such as N202.1A cells with FVB background) delayed the carcinogenic process, depending on the presence of appropriate adjuvant stimuli (24). To study the immunogenic ability of CCR7-engineered cells, we used 1A-CCR7- 


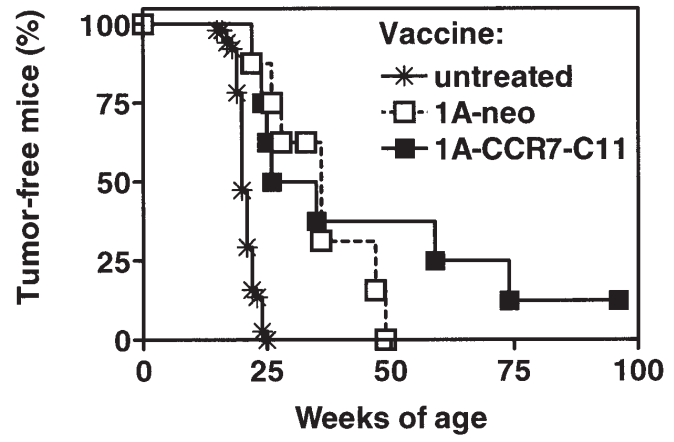

Figure 4. Vaccination with CCR7-engineered cells delayed mammary carcinogenesis in HER-2/neu transgenic mice. Both cell vaccines (1A-neo and 1A-CCR7-C11) induced a significant inhibition of carcinogenesis with respect to untreated mice $(\mathrm{p}<0.01$, Mantel-Haenzel test).

C11 cells as a preventive vaccine in BALB-neuT mice compared to the 1A-neo transduction control cells (Fig. 4). Both cell vaccines induced a significantly delayed carcinogenesis with respect to untreated mice. Prevention afforded by CCR7-engineered cells was not statistically different from that of the transduction controls. However two long-term tumor-free mice were present in the 1A-CCR7-C11-vaccinated group; one developed a mammary tumor at 59 weeks of age, while the other remained tumor-free for its entire life $(>2$ years).

\section{Discussion}

To study the role of the chemokine receptor CCR7 in the metastatic process of mammary cancer cells, we choose a gene-transduction approach and two experimental model systems with different etiology, molecular features and metastatic ability.

The TS/A cell line was derived from a mammary carcinoma that arose spontaneously in a retired breeder female of BALB/c strain (18). It is characterized by a high ability to give rise to spontaneous lung metastases from subcutaneously grown tumors.

The N202.1A cell line was derived from a mammary carcinoma that arose in HER-2/neu transgenic mice (19); these mice carry a rat HER-2/neu transgene driven by the MMTV-LTR promoter that causes HER-2/neu overexpression in the mammary gland and consequent mammary carcinogenesis (23). N202.1A cells maintain a high expression of HER-2/neu and are tumorigenic in the syngeneic hosts, with a low ability to give rise to spontaneous lung metastases. However N202.1A cells can give rise to lung metastases when injected directly into the blood stream, thus showing that they fail in the early phases of the metastatic process (such as local invasion), but that they can complete the late phases, such as arrest and growth in the pulmonary parenchyma.

The murine chemokine receptor CCR7 gene transduced in both cell lines was functional, since it mediated a migratory response to CCL21 (one of the two CCR7 ligands), within the same dose interval previously reported for human breast cancer cells (14). CCR7 expression did not consistently alter any of the in vitro growth features examined, including proliferation in the presence of CCL21. A few non-leukocyte cell types expressing chemokine receptors were reported to have increased proliferation in the presence of the appropriate chemokine; CCR7-positive kidney mesangial cells showed a proliferative response to CCL21 $(25,26)$, whereas CXCR4positive human pancreatic tumor cells had enhanced proliferation in the presence of CXCL12 (27). Our data show that CCR7-expressing mammary cancer cells behave differently from other CCR7-expressing non-leukocyte cell types. This also suggests that the effects of a transduced CCR7 gene may depend on the cells chosen as recipients.

Some data reported in the literature on the role of chemokine receptors in the metastatic process were based on models which showed coexpression of CXCR4 and CCR7 (14). Both cell lines used as transduction recipients in this study (TS/A and N202.1A) expressed very low levels of CCR7 and were negative for CXCR4, as found in our PCR and microarray studies (unpublished results), thus constituting good models with which to study the effects of CCR7 alone in the absence of CXCR4 expression. We did not find significant effects of CCR7 expression on the tumorigenic and spontaneous metastatic ability, regardless of the HER-2/neu expression of the transduction recipient. The lack of effect was observed both with the TS/A model, which was able to metastasize spontaneously and therefore could efficiently complete early phases of the metastatic process, and with the N202.1A model, whose low metastatic ability could have easily allowed evaluation of the effects of a prometastatic candidate gene. Under our conditions we never observed locoregional metastatic lymph nodes at necropsy (data not shown), hence, even if the cells could be attracted to the lymph nodes, they did not appear to proliferate in that environment.

Transduced CCR7 expression was associated with a significant inhibition of the late post-intravasation phases of the metastatic process. A possible explanation for this phenomenon could be a better antigen presentation. CCR7 transduction was reported to increase the migratory ability of a dendritic cell vaccine into regional lymph nodes (28). Tumor cells are generally poor antigen-presenting cells. However, a study on different murine models has shown the crucial role played by tumor cell localization to secondary lymphoid organs in order to obtain a cytotoxic T cell response; the lack of expression of costimulatory molecules by tumor cells being almost irrelevant (29). To test this hypothesis we studied the immunogenic ability of CCR7-engineered cells in a prophylactic vaccine approach for prevention of mammary carcinogenesis. CCR7-transduced cell vaccine succeeded in the long-term control of mammary tumorigenesis in $25 \%$ of the HER-2/neu transgenic females, suggesting an increased immunogenicity of CCR7-engineered cells.

\section{Acknowledgements}

This study was supported by grants from the Italian Ministry for Education, University and Research, the University of Bologna, and the Italian Association for Cancer Research. S. Croci was awarded a fellowship from University of Bologna, Italy. A. Palladini was awarded a fellowship from Italian Foundation for Cancer Research, Milan, Italy. 


\section{References}

1. Hanahan D and Weinberg RA: The hallmarks of cancer. Cell 100: 57-70, 2000.

2. Christofori G: New signals from the invasive front. Nature 441: 444-450, 2006.

3. Steeg PS: Tumor metastasis: mechanistic insights and clinical challenges. Nat Med 12: 895-904, 2006.

4. Kang H, Mansel RE and Jiang WG: Genetic manipulation of stromal cell-derived factor-1 attests the pivotal role of the autocrine SDF-1-CXCR4 pathway in the aggressiveness of breast cancer cells. Int J Oncol 26: 1429-1434, 2005.

5. Hoon DS, Kitago M, Kim J, Mori T, Piris A, Szyfelbein K, Mihm MC Jr, Nathanson SD, Padera TP, Chambers AF, Vantyghem SA, MacDonald IC, Shivers SC, Alsarraj M, Reintgen DS, Passlick B, Sienel W and Pantel K: Molecular mechanisms of metastasis. Cancer Metastasis Rev 25: 203-220, 2006.

6. Balkwill F: Cancer and the chemokine network. Nat Rev Cancer 4: 540-550, 2004

7. Kakinuma T and Hwang ST: Chemokines, chemokine receptors, and cancer metastasis. J Leukoc Biol 79: 639-651, 2006.

8. Zlotnik A: Chemokines and cancer. Int J Cancer 119: 2026-2029, 2006.

9. Li S, Huang S and Peng SB: Overexpression of G proteincoupled receptors in cancer cells: Involvement in tumor progression. Int J Oncol 27: 1329-1339, 2005.

10. Mantovani A, Sica A, Sozzani S, Allavena P, Vecchi A and Locati M: The chemokine system in diverse forms of macrophage activation and polarization. Trends Immunol 25: 677-686, 2004.

11. Zeelenberg IS, Ruuls-Van Stalle L and Roos E: Retention of CXCR4 in the endoplasmic reticulum block dissemination of a T cell hybridoma. J Clin Invest 108: 269-277, 2001.

12. Wiley HE, Gonzalez EB, Maki W, Wu MT and Hwang ST: Expression of CC chemokine receptor-7 and regional lymph node metastasis of B16 murine melanoma. J Natl Cancer Inst 93: 1638-1643, 2001.

13. Gupta PB, Kuperwasser C, Brunet JP, Ramaswamy S, Kuo WL, Gray JW, Naber SP and Weinberg RA: The melanocyte differentiation program predisposes to metastasis after neoplastic transformation. Nat Genet 37: 1047-1054, 2005.

14. Muller A, Homey B, Soto H, Ge N, Catron D, Buchanan ME, McClanahan T, Murphy E, Yuan W, Wagner SN, Barrera JL, Mohar A, Verastegui E and Zlotnik A: Involvement of chemokine receptors in breast cancer metastasis. Nature 410: 50-56, 2001.

15. Liang Z, Wu T, Lou H, Yu X, Taichman RS, Lau SK, Nie S, Umbreit $J$ and Shim $H$ : Inhibition of breast cancer metastasis by selective synthetic polypeptide against CXCR4. Cancer Res 64: 4302-4308, 2004

16. Smith MC, Luker KE, Garbow JR, Prior JL, Jackson E, Piwnica-Worms D and Luker GD: CXCR4 regulates growth of both primary and metastatic breast cancer. Cancer Res 64: 8604-8612, 2004.

17. Li YM, Pan Y, Wei Y, Cheng X, Zhou BP, Tan M, Zhou X, Xia W, Hortobagyi GN, Yu D and Hung MC: Upregulation of CXCR4 is essential for HER2-mediated tumor metastasis. Cancer Cell 6: 459-469, 2004
18. Nanni P, De Giovanni C, Lollini PL, Nicoletti G and Prodi G TS/A: a new metastasizing cell line from a BALB/c spontaneous mammary adenocarcinoma. Clin Exp Metastasis 1: 373-380, 1983

19. Nanni P, Pupa SM, Nicoletti G, De Giovanni C, Landuzzi L, Rossi I, Astolfi A, Ricci C, De Vecchi R, Invernizzi AM, Di Carlo E, Musiani P, Forni G, Menard S and Lollini PL: $\mathrm{p} 185$ (neu) protein is required for tumor and anchorageindependent growth, not for cell proliferation of transgenic mammary carcinoma. Int J Cancer 87: 186-194, 2000.

20. Iwasaki A and Kelsall B: Localization of distinct Peyer's patch dendritic cell subsets and their recruitment by chemokines macrophage inflammatory protein (MIP)-3alpha, MIP-3beta, and secondary lymphoid organ chemokine. J Exp Med 191: 1381-1394, 2000.

21. Krautwald S, Ziegler E, Forster R, Ohl L, Amann K and Kunzendorf U: Ectopic expression of CCL19 impairs alloimmune response in mice. Immunology 112: 301-309, 2004.

22. Guy CT, Webster MA, Schaller M, Parsons TJ, Cardiff RD and Muller WJ: Expression of the neu protooncogene in the mammary epithelium of transgenic mice induces metastatic disease. Proc Natl Acad Sci USA 89: 10578-10582, 1992.

23. Boggio K, Nicoletti G, Di Carlo E, Cavallo F, Landuzzi L, Melani C, Giovarelli M, Rossi I, Nanni P, De Giovanni C, Bouchard P, Wolf S, Modesti A, Musiani P, Lollini PL, Colombo MP and Forni G: Interleukin 12-mediated prevention of spontaneous mammary adenocarcinomas in two lines of Her-2/ neu transgenic mice. J Exp Med 188: 589-596, 1998.

24. Nanni P, Nicoletti G, De Giovanni C, Landuzzi L, Di Carlo E, Cavallo F, Pupa SM, Rossi I, Colombo MP, Ricci C, Astolfi A, Musiani P, Forni G and Lollini PL: Combined allogeneic tumor cell vaccination and systemic interleukin 12 prevents mammary carcinogenesis in HER-2/neu transgenic mice. J Exp Med 194: 1195-1205, 2001

25. Banas B, Wornle M, Berger T, Nelson PJ, Cohen CD, Kretzler M, Pfirstinger J, Mack M, Lipp M, Grone HJ and Schlondorff D: Roles of SLC/CCL21 and CCR7 in human kidney for mesangial proliferation, migration, apoptosis, and tissue homeostasis. J Immunol 168: 4301-4307, 2002.

26. Wornle M, Schmid H, Merkle M and Banas B: Effects of chemokines on proliferation and apoptosis of human mesangial cells. BMC Nephrol 5: 8, 2004

27. Marchesi F, Monti P, Leone BE, Zerbi A, Vecchi A, Piemonti L, Mantovani A and Allavena P: Increased survival, proliferation, and migration in metastatic human pancreatic tumor cells expressing functional CXCR4. Cancer Res 64: 8420-8427, 2004.

28. Okada N, Mori N, Koretomo R, Okada Y, Nakayama T, Yoshie O, Mizuguchi H, Hayakawa T, Nakagawa S, Mayumi T, Fujita T and Yamamoto A: Augmentation of the migratory ability of DC-based vaccine into regional lymph nodes by efficient CCR7 gene transduction. Gene Ther 12: 129-139, 2005.

29. Ochsenbein AF, Sierro S, Odermatt B, Pericin M, Karrer U, Hermans J, Hemmi S, Hengartner $\mathrm{H}$ and Zinkernagel RM: Roles of tumour localization, second signals and cross priming in cytotoxic T-cell induction. Nature 411: 1058-1064, 2001. 